\title{
The Rising Goes Digital : Century Ireland.ie
}

\section{Anne Goarzin}

\section{(2) OpenEdition}

\section{Journals}

\section{Electronic version}

URL: http://journals.openedition.org/etudesirlandaises/5317

DOI: 10.4000/etudesirlandaises.5317

ISSN: 2259-8863

\section{Publisher}

Presses universitaires de Caen

\section{Printed version}

Date of publication: 29 November 2017

Number of pages: $75-88$

ISBN: 978-2-7535-7388-8

ISSN: 0183-973X

\section{Electronic reference}

Anne Goarzin, «The Rising Goes Digital : Century Ireland.ie », Études irlandaises [Online], 42-2 | 2017, Online since 29 November 2017, connection on 17 September 2019. URL : http://

journals.openedition.org/etudesirlandaises/5317 ; DOI : 10.4000/etudesirlandaises.5317 


\title{
The Rising Goes Digital : Century Ireland.ie
}

\author{
Anne GoArzin \\ Université Rennes 2
}

Abstract

The "decade of commemorations" initiated on May 1st, 2013 in Ireland has brought about a wide range of new media projects which aim at remembering events and understanding how ideals are elaborated and how famous or anonymous figures and women, anonymous or not chose to enact them, focusing on the 1913-23 period. This paper examines the Century Ireland website [http://www.rte.ie/centuryireland/]. It proposes to assess how archival material related to the Rising contributes to the elaboration of an alternative discourse that takes affect and immateriality into account and engages the users of these interfaces.

Keywords: 1916, The Rising, Century Ireland.ie, digital studies, archives, affect theory, Post-Internet.

\section{Résumé}

La "décennie de commémorations" qui a été initiée en 2013 en Irlande a fait émerger de nombreux projets sur le web. Ils ont pour objectif de se souvenir et de comprendre comment se sont mobilisés les idéaux d'hommes et de femmes connu(e)s ou anonymes durant la période 1913-23. Cet article sintéresse au site web Century Ireland [http://www.rte.ielcenturyireland/]. Il sintéresse au glissement qui sopère depuis les archives matérielles du soulèvement de 1916 vers une histoire alternative du soulèvement qui prend en compte l'affect et l'immatériel et implique les utilisateurs des interfaces.

Mots clés : 1916, Soulèvement de 1916, Century Ireland.ie, études numériques, archives, théorie de l'affect, post-Internet

The "decade of commemorations" initiated on May 1", 2013, in Ireland has brought about a wide range of new media projects which aim at remembering events and understanding how ideals are elaborated and how men and women chose to enact them over the period 1913-23. Two distinct online platforms were launched as part of this commemorative effort in Ireland. As interfaces, they can be understood as "places or surfaces where two bodies or systems come together". They can involve a human and a machine (for example, a computer, a phone, a

1. Nicholas Gane, David Beer, New Media : The Key Concepts, London, New York, New Delhi, Sydney, Bloomsbury (2008), 2012, p. 55. 
tablet) or two humans (individuals engaging in a debate or dialogue via a social network or a discussion forum), or perhaps two machines. Media scholars Nicholas Gane and David Beer stress that "interfaces enable the formation of networks across or between different beings, objects or media. Interfaces are thus not confined to new media, for we engage with people and technical objects frequently in our everyday lives, and not always through the use of digital technologies". Images, books, diaries and letters are therefore points of contact between humans and digital technologies.

One significant example is the project entitled "Inspiring Ireland 1916: Weaving Public and Private Narratives". It has the support of the Minister for the Diaspora and is conveyed through the Digital Repository of Ireland (DGI). As a collaborative project which features cultural artefacts and stories of 1916, it calls for digital users in Ireland and abroad to contribute their own resources to the platform. As an archive of the digital age, it stores personal memorabilia such as a "digitized photos, diaries, posters, aural recordings, video, and ephemera ${ }^{3 \text { " }}$ and makes them available to the public following an online submission and a selection process ${ }^{4}$ :

As part of the Inspiring Ireland 1916 project, a number of collection days are being held across the country and abroad, allowing members of the public to bring in documents, objects and other material relating to the 1916 Easter Rising and tell the story attached to them. Items will be digitized and returned to their owners.

This collection is made up of the digital objects created from the items donated by the public at those collection days. The items include personal correspondence, medals, souvenirs, pamphlets and postcards, ephemera and other personal memorabilia.

The collection days present an opportunity for members of the public to contribute to the Inspiring Ireland project and share their personal and family narratives of the Easter Rising 5 .

2. Ibid.

3. "Inspiring Ireland 1916: Weaving Public and Private Narratives' uses fascinating objects - digitized photos, diaries, posters, aural recordings, video, and ephemera - to tell the stories that surround the Rising, and paint a picture of everyday lives in 1916. Combining expert narrative with iconic objects from the National Archives of Ireland, the National Library of Ireland, the National Museum of Ireland and RTÉ Archives alongside 'found' objects from private collections, Inspiring Ireland 1916 creates a dynamic, multi-media reflection on the people, events, and legacy of 1916." See [http://dri.ie/launch-inspiring-ireland-1916] (last accessed January 11, 2017).

4. The website's guide to deposit the archives stipulates "Assess your collection in terms of DRI's remit and collection policy. Our collection policy will provide you with an overview of the types of data, digital assets and collections which the Digital Repository of Ireland aims to preserve. You should also review the file formats, metadata and the copyright status of your collection. If your research involves people, you should also review the DRI Restricted Data policy." [http://www.dri.ie/about/guide-to-deposit](last accessed June 26, 2017).

5. "Inspiring Ireland 1916 - Public Memorabilia" [https://repository.dri.ie/catalog/1c18df827], and Letters of 1916. 
There is a notable shift towards an increasingly individualized archive. Indeed as Gane and Beer remarked as early as 2008: "For now, there is less of a 'gatekeeper' approach to public archives as these are often assembled through public work of individuals [...] and tend to be policed through the local and decentralized actions of their users (although this may well be starting to change) ${ }^{6}$." By extension, moving away from the archival aspect of the Digital Repository Ireland, this remark ties in with Lev Manovich's observation that the computer has become a filter for culture, providing "cultural interfaces [...] which structure 'the ways in which computers present and allow us to interact with cultural data."”

\section{Century Ireland: Online news and simulated real-time}

In order to illustrate these changes in the uses of and in the relation with new media, I propose to focus on Century Ireland as a case study. An online project hosted by RTÉ, Century Ireland is funded by the Department of Arts, Heritage and the Gaeltacht and curated by Boston College History Professor Michael Cronin. My aim here is to assess how the technological environment of Century Ireland engages with the question of the archive, and to examine the relation between users and media technology. I will also interrogate the creative potential of such assemblages.

The Century Ireland interface imitates the format of an online newspaper. It integrates a blog (which serves as an archive of previous blog posts), a Twitter feed, and features commercial posters dating back to the period of reference (the early to mid-20 $0^{\text {th }}$ century). An "Archive" section proper also lists past issues of Century Ireland going back to 2013. The overall framework interrogates the historical perception of Ireland at the time and its relation with other countries and nations in time and space (fig. 1). The platform uses the device of simulated realtime, implying that the user is willing to accept that we are speaking of 1916 as if it were today. It is this fundamental discontinuity that allows him/her to assemble with the experiences featured on the website 8 . The "online newspaper" refers to past events in the present tense and keeps track of them by tagging them on Twitter with the hashtag \#onthisday or @CenturyIRL (fig. 2). For example, the online edition for June 1917/2017 features headers such as "Extraordinary celebrations as final rebellion prisoners released" (19 June 1917) or "Eamon de Valera

6. Nicholas Gane, David Beer, New Media..., op. cit., p. 11.

7. Lev Manovich (The Language of New Media, Cambridge, MA., MIT Press, 2001, p. 70), cited by N. Gane, D. Beer, New Media..., op. cit., p. 56.

8. By acknowledging this "un-reality", one is also authorized to question more generally the traditional idiom of culture. Indeed the inherent risk of a website is that it might be seen as "filtering" mediation or as potentially manipulating, or culturally homogenizing. 
to run for vacant East Clare seat" (20 June 1917). There are a few exceptions to this simulated "real-time" mode however, especially with the insertion of longer reads available through the slideshow, which offer in-depth analyses and interpretations of key moments or social history in the past tense (for example, "Messines Remembered" or "White weddings in war-time Ireland").

What kind of archives does the website offer? Looking back, Mike Featherstone $^{9}$ has argued that as it became a central feature of the onset of modernity, the archive could no longer be envisaged as a collection of documents in a walled, official government record. As a result the question of what went into the archives and what could be retrieved by whom became crucial. He has also emphasized that "the archive is a crucial site for national memory [...] and that because of this, it is also 'a place for creating and re-working memory ${ }^{10}$ '”.

Types of archives today are no longer limited to the guarded confines of an official depository of knowledge. As archives online open, they can be seen as a benefit for internet users. They can also be interpreted in a broader sense as more personal documents are found in web cultures and circulated on a variety of web devices - phones, computers and tablets. Tellingly, one of the main changes over the last decade or so has been the rise of the figure of the "prosumer". This neologism defines a user who is not merely consuming content but also also producing it, especially through social media where numerous instances of what sociologist Zygmunt Bauman has described as a "confessional society ${ }^{11}$ " are to be found.

The technological mediation afforded by Century Ireland makes for an interesting entanglement of historical material archived online and of the individual perception of users, who are now familiar with the creation and circulation of their own archives (starting with Facebook). They are used to taking on an agential role in social networks. Reflecting on this, David Beer points that

we now need to understand how archiving is central to culture and how different systems of classification lead to different understandings of cultural forms and different cultural encounters. Bowker and Star's $[\ldots]$ suggestion that we uncover these processes by taking three steps is pertinent here : "recognizing the balancing act of classifying", "rendering voice retrievable", and "being sensitive to exclusions ${ }^{12 "}$ ".

9. Mike Featherstone ("Archive", in Theory Culture, and Society, 23, (2-3), 591-6, 594), quoted by David Beer in Popular Culture and New Media: The Politics of Circulation, Basingstoke, New York, Palgrave Macmillan, 2013, Kindle Version, p. 47.

10. D. Beer, Popular Culture and New Media..., p. 47.

11. Ibid., p. 52.

12. Ibid., p. 62. 
Here, I argue that what goes on when browsing through the interfaces and its ramifications is not a waste of time. Jennifer Pybus ${ }^{13}$ insists that such activity should be envisaged as a combination of "immaterial labor" (as she characterizes the online approach of the digital user) and of an attention to archival material (letters, objects, or oral testimonies). Granted, the organizational display and choice of online archives owes much to human agency and especially to the expertise of historians and scholars ${ }^{14}$. Yet on the other hand, new media technologies fuel affective perceptions which might be less controlled. Simultaneously, the visual image has become a ubiquitous instrument that zooms in, connects one to the internet, moves things on the screen from one place to another, changes the temperature and so on. New practices have developed alongside these new forms: "New media moves us from identification to action 15", Manovich claims. As they become instruments, they allow us to relate differently to "reality" and to interact with them.

A striking example of this is the interactive Dublin Rising created, powered and conveyed by the global, Dublin-based Google through the online Google Cultural Institute ${ }^{16}$. Through the click of an icon or a shift left or right, it provides the user with a better understanding, and more importantly with a virtual experience of the space of the city as well as of the extent of its destruction ${ }^{17}$ (fig. 3.1 and 3.2).

\section{Entangled territories: Practicing Century Ireland}

Century Ireland is thus much more than another online environment commemorating 1916, and I suggest that the website in fact embodies material relations.

13. "The term affective labor"... grasps "the corporeal and intellectual aspects of the new forms of production, recognizing that such labor engages at once with rational intelligence and with the passions or feeling" (Jennifer Pybus in Ken Hillis and Susanna Paasonen and Michael Petit (eds.) Networked Affect, Cambridge, Massachusetts, The MIT Press, 2015, p. 7).

14. "Century Ireland is produced by a team of researchers at Boston College Ireland and the project is funded by the Department of the Arts, Heritage and the Gaeltacht." The team includes historians Mike Cronin, Mark Duncan and Paul Rouse as well as several scientific advisors like Catríona Crowe, Head of Special Projects at the National Archives of Ireland. [http://www.rte.ie/centuryireland/index.php/about-century-ireland/] (last accessed November 7 2017).

15. Lev Manovich, Ibid., in N. Gane and D. Beer, p. 59.

16. [https://www.google.com/culturalinstitute/beta/project/easter-rising-1916] (last accessed June 26, 2017).

17. Here is an example of what the app proposes to explore: "The destroyed Liberty Hall building being viewed from modern day O'Connell Bridge. [...] There are even digital copies of significant documents relating to the location and audio recordings of eyewitness accounts. For example, stop four on the tour brings users to Dublin Castle and City Hall where the first fatalities of the Rising died, Constable James O'Brien and Captain Seán Connolly. One of the most valuable accounts of these deaths is Helena Molony, one of the rebels who went to take the castle. "Dublin Rising 1916-2016" allows users click on an actor's rendition of her testimony as they look at the scene as it exists today." See [https://dublinrising.withgoogle.com/about/] (Last accessed Jan 11, 2017). 
Here, the notion of "embodied virtuality" coined by Katherine Hayles seems relevant : she proposes that there is a complex network of relations or an interweaving that occurs between "the technologies of information as well as the biological, social, linguistic and cultural changes that initiate, accompany and complicate their development ${ }^{18}$. This entails that the body should not be seen as distinct or outside of cultural imagings such as those of Century Ireland: "Information, like humanity, cannot exist apart from the embodiment that brings it into being as a material entity in the world ${ }^{19}$ ", Hayles says. She sees the human as interfacing with, rather than as isolated from technological environments and flows of information and data and argues that "new forms of subjectivity [...] might be born out of the interface between human bodies and computer-based technologies ${ }^{20}$." Another consequence of this is also that the circulation of information online via a website and social networks and the deliberate, didactic and linear sorting of events and dates is likely to be questioned by new, less institutional interactions.

In this sense, the platform in itself fully constitutes a valid topic to be studied through the prism of cultural studies. Indeed cultural studies' role, according to theorist Raymond Williams, is to address the "structure of feeling" and to try and answer the question of "what it feels to be alive at a certain time and place ${ }^{21}$ ". This also implies taking stock of the way in which all elements in "a whole way of life" are related and how we live those relationships, Lawrence Grossberg says :

Everyday life is not simply the material relationship; it is a structure of feeling, and this is where I want to locate affect. This is what I call "territorializing." It is about how you can move across those relationships, where you can and cannot invest, where you can stop/rest and where you can move and make new connections, what matters and in what ways ${ }^{22}$.

I thus propose to examine Century Ireland as a virtual territory where users may experiment with the structure of feeling and affective apparatuses. The ubiquity of forms afforded by Century Ireland allows users to choose and select the elements (stories, events, images) to which they feel attuned. As a result, what occurs online is an interconnection or co-presence of human (reader, viewer) and non-human entities (objects, sounds, the computer, even the web) ${ }^{23}$. Century

18. Katherine Hayles, How We became Posthuman : Virtual Bodies in Cybernetics, Literature and Informatics, Chicago, Chicago U.P., 1999, p. 29.

19. Ibid., p. 49.

20. N. Gane, D. Beer, New Media..., op. cit., p. 13 (referencing Hayles, ibid.)

21. Lawrence Grossberg, "Affect's Future", in The Affect Theory Reader, p. 310.

22. Ibid., p. 313.

23. From a Latourian perspective, this is Actor-Network Theory, where "actors" refers not to individual intention and action, but to the co-presence and relations of entities of all kinds (human, animal, neither). See Bruno Latour, Reassembling the Social: An Introduction to Actor-Network-Theory (Oxford, OUP, 2007) and An Inquiry Into Modes of Existence (Cambridge, Harvard UP, 2014). In Karen Barad's terms, such exchanges and transfor- 
Ireland allows one to err through the various manifestations and relations between events, actions and reactions. In this regard the structure of the website nods to the relative confusion of the Rising, as does poet Theo Dorgan: "The Rising was not a seamlessly-conceived process, it contained in itself a number of divergences and contradictions, and even as it got under way it began to revise itself drastically, not least in its military aims and objectives ${ }^{24 "}$ ".

Beyond clear-cut opinions and assessments of the event, of its outcome or its lasting consequences, the digitized material of Century Ireland elicits various affective reactions. It offers an insight into the various shapes and guises of affect, this

generally other than conscious knowing, vital forces beyond emotions that can serve to drive us towards movement, toward thought and extension, that can likewise suspend us (as if in neutral) [...] or that can even leave us overwhelmed by the world's obstinacies and rhythms, its refusals as much as its invitations ${ }^{25}$.

These affective qualities, rather poetically termed by affect theorists Gregg and Seigworth "an inventory of shimmers ${ }^{26 "}$ can be figured in many ways, they say,

[...] as excess, as autonomous, as impersonal, as the ineffable, as the on-goingness of process, as pedagogico-aesthetic, as virtual, as shareable (mimetic), as sticky, as collective, as contingency, as threshold or conversion point, as immanence of potential (futurity), as the open, a vibrant incoherence that circulates about zones of cliché and convention, as a gathering place of accumulative disposition $\mathbf{s}^{27}$.

We might then envisage Century Ireland as a mediascape where the all-out internet medium becomes entangled with the more traditional paradigm of the archive. An online cultural object with a commemorative ambition, it might take the user down the straightforward path signposted with solid visual and contextual material, dates, chronologies, key figures or symbolic objects. But the nature of the medium allows the user to simultaneously go down the other, less predictable path that leads to the entanglement of social networks.

mations are called entanglements. See Karen Barad, Meeting the Universe Halfway, Quantum Physics and the Entanglement of Matter and Meaning (Durham and London, Duke UP, 2007) and Karen Barad, "Posthumanist Performativity: Toward an Understanding of how Matter comes to Matter”, Signs: Journal of Women in Culture and Society, University of Chicago, Vol. 28. No. 3, p 801-831, 2003.

24. Theo Dorgan, "To Rise Again, Revising the Rising”, Études Irlandaises : L'Irlande et la république, passée présente et à venir/Ireland's Republic Past, Present and Future (eds. Clíona Ní Riordán and Karin Fischer), vol. 41, no. 2, 2016, p. 137.

25. Melissa Gregg and Gregory J. Seigworth (eds.) The Affect Theory Reader, Durham and London, Duke U.P., 2010, p. 1.

26. Gregg and Seigworth (eds.), The Affect Theory Reader, p. 1.

27. Ibid., p. 9. 
This might also lead us to acknowledge that being online is now a "default condition" and that the internet is "all over", as contemporary artist Artie Vierkant mischievously asserts ${ }^{28}$. Far from being finished, it is virtually "all-out" and "everywhere":

Simply put, the relationship between reality and its online mirror has changed to the point that the real and the digital have merged into a single thing: Isn't Google real? ... It's rather related to a general shift from modem connection (being online as a conscious choice) to seamless connectivity (being online as a default condition)... from small communities to online crowds $^{29} \ldots$

And while Vierkant theorizes the potential of this moment he terms "PostInternet" for the contemporary visual arts, his approach is also relevant for our study because it calls for approaches beyond the internet as medium in its materiality, and beyond methods of presentation or dissemination of the object. Even though Century Ireland does not claim a status as a work of art, it is undoubtedly located in the post-Internet age where ubiquitous authorship and networked culture exemplify recent cultural shifts and changing technological habits. The website is thus not merely informative, commemorating past events. Rather, the user might become entangled in the present with what she/he encounters there. The interface presents objects and encourages their dissemination online, through sharing images, sounds or links via Twitter, Facebook or YouTube ${ }^{30}$.

In this way, Century Ireland reactivates the discussion on how we relate to archival objects and to other users. Do we make the conscious choice of a phenomenological concern about things, entailing intentional emotions? Or is our rela-

28. See Artie Vierkant, "The Image Object Post-Internet”, 2010, [http://jstchillin.org/artie/pdf/The_Image_Object_Post-Internet_us.pdf.] The term calls for further explanation : coined in 2009 by artist Marisa Olson, it has been applied mostly to art but it may be expanded to cultural objects. Vierkant situates it between two artistic and more broadly, two cultural modes, while insisting that the "post-Internet" is not a discrete moment. On the one hand "New Media Art" [in the late 1990s] was focused on the materiality of the media and the "specific workings of novel technologies rather than a sincere exploration of cultural shifts in which that technology plays only a small role". On the other, "Conceptualist Art" [initiated in the 1960s] ignored the physical substrate "in favor of disseminating the artwork as image, context, or instruction" - and did so by examining the work's reception through language (within and around it). In other words, the materiality of the technology and its conceptual potential have tended to be examined separately. (See also Hito Seyerl, “Too Much World: Is the Internet Dead?” [http://www.e-flux.com/journal/49/60004/too-much-world-is-theinternet-dead/] (Last accessed January 12, 2017). Further reading in Domenico Quaranta, "Internet State of Mind: Where can Medium Specificity Be Found in Digital Art ?” p. 426 in Lauren Cornell and Ed Halter, Mass Effect: Art and the Internet in the Twenty-First Century, Cambridge, Massachusetts, The MIT Press, 2015).

29. Domenico Quaranta, "Internet State of Mind: Where can Medium Specificity Be Found in Digital Art?", p. 426 in Lauren Cornell and Ed Halter, Mass Effect: Art and the Internet in the Twenty-First Century, Cambridge, Massachusetts, The MIT Press, 2015.

30. Sarah Ahmed, The Cultural Politics of Emotion, $2^{\text {nd }}$ edition, New York, Routledge, 2014, p. 210. (Italics in original). 
tion to them non-intentional, impersonal, unmediated affect, and are we affected by things? In The Cultural Politics of Emotion, Sarah Ahmed insists that an either/ or answer can only be provided in a perfect intellectual world of definitions. She suggests that we "explor[e] the messiness of the experiential, how bodies unfold into worlds, and the drama of contingency, how we are touched by what comes near ${ }^{31}$ ".

As a virtual territory where collective history is archived in order to be commemorated and individual stories are remembered, and as a post-Internet platform providing default connectivity and dissemination as well as a historical linear narrative Century Ireland is a captivating place. Here, the non-intentionality of affect and the intentionality of emotion meet ${ }^{32}$. This calls in turn for an examination of how our browsing the platform may translate into new practices. I will argue that the confrontation with the archive produces a tension towards futurity which assembles past and present affects across the disseminated narratives of the news or through personal stories. It is this re-appropriation and recreation of stories that makes the archive lean towards artistic creation.

\section{圈 Creative Possibilities}

Going back to the notion of the archive, let us examine how Michel Foucault's complex definition of the archive becomes specially relevant here. In The Archeology of Knowledge and the Discourse on Language, the philosopher defined the archive as a practice and as a virtuality or a potential. He wrote that "between tradition and oblivion, it reveals the rules of a practice that enables statements both to survive and to undergo regular modification. It is the general system of formation and transformation of statements ${ }^{33}$ ". Jennifer Pybus, a keen Foucault reader, adds that instead of a sum of texts or a passive corpus, the archive according to Foucault is "immanently productive" and operates as that "which differentiates discourses in their multiple existence and specifies them in their own duration ${ }^{34 "}$. Rather than comforting our sense of subjectivity and history, it disturbs it:

Its locus is the gap between our own discursive practices. [...] it deprives us of our continuities; it dissipates that temporal identity in which we are pleased to look at ourselves when we wish to exorcise the discon-

\footnotetext{
31. Ibid., p. 210.
}

32. "For Massumi", Sara Ahmed writes, "if affects are pre-personal and non-intentional, emotions are personal and intentional; if affects are unmediated and escape signification; emotions are mediated and contained by signification." (In Ahmed, p. 207.)

33. Michel Foucault, The Archaeology of Knowledge and the Discourse on Language, New York, Vintage, 1982, p. 130

34. Jennifer Pybus quoting Foucault, in "Accumulating Affect: Social Networks and Their Archives of Feelings", in Ken Hillis, Susanna Paasonen, Michael Petit (eds.), Networked Affect, Cambridge, Massachusetts, The MIT Press, 2015, p. 239. 
tinuities of history; it breaks the thread of transcendental teleologies [...] it $[\ldots]$ bursts open the other, and the outside ${ }^{35}$.

Thus, far from merely recovering a discourse on the forgotten and recovered origin, Foucault conceives of the archive as a "dispersion that we are and make ${ }^{36 "}$. It might thus be argued that Century Ireland implements this discourse on the archive by conferring to it the dimension of affect, or life, or vitality.

Significant material objects in the Rising are referenced by Lisa Godson and Joanna Brück in the section devoted to material culture: "Among the objects associated with the Easter Rising, the most iconic include uniforms, flags and the Proclamation of the Irish Republic ${ }^{37}$." But it should be noted that in this case, the archive does not stand merely as historical evidence ${ }^{38}$. Instead, these objects embody and perform the Rising by allowing to bring the public in contact or to connect their individual "flow" with other entities and stories, in keeping with Bruno Latour's theory of the social as "associations" and "complex and dynamic connections" - rather than as a "special part of reality", a projection, a passive entity $^{39}$. The platform makes visible the changing perception of symbols of the rebellion and enables the forging of connections between humans and objects with, and across media.

More importantly, what is recreated is "actual / carnal connections through the virtual ${ }^{40 "}$ as Lisa Blackman writes in Immaterial Bodies, disputing the aloofness of the web-user as mere flâneur. For example, the digital user of the Century Ireland platform is able to relate to short pieces of material information (News in Brief: "Recipes for wives and maids: Fish fritters ${ }^{41}$ "). If there is time, she/he might alternatively opt for extensive analyses ("Focus") or dwell on the context with the "Themes ${ }^{42 "}$. She/he may also choose to pass on a particular event or conversely, to engage with the specificity of an archived piece through lesson plans for Junior

35. M. Foucault, The Archaeology of Knowledge..., op. cit., p. 131.

36. Ibid.

37. [http://www.rte.ie/centuryireland/index.php/articles/material-culture-and-1916] (last accessed Jan 11, 2017).

38. Ibid:: "Now museum collections are being used to tell different histories. Although museums in Northern Ireland tended to avoid the topic of the Rising from its foundation through the 'Troubles', a Christmas card (designed by George Irvine, a Protestant and member of the Irish Republican Brotherhood) recently acquired by Fermanagh County Museum is one of a variety of items relating to the Rising that provide opportunities for difficult, contentious and complex histories to be addressed. Here, the power of objects lies not in their use as 'evidence' but as pivots around which different understandings of the Rising can be explored and discussed."

39. N. Gane, D. Beer, New Media..., op. cit., p. 31. Latour says that "What is important in the word network is the word work. You need work in order to make the connection".

40. See Lisa Blackman, Immaterial Bodies: Affect, Embodiment, Mediation, Thousand Oaks, Calif., Sage Publications Ltd., 2012, p. 67.

41. [http://www.rte.ie/centuryireland/index.php/blog/recipes-for-wives-and-maids-fish-fritters] (last accessed January 11, 2017).

42. These thematic approaches might concern Gallipoli, Sir Roger Casement, The Battle of the Somme or the Lockout, which open up onto online exhibits of their own. 
cycle students, where archival material such as the half-copy of the Proclamation and visual art works relevant to the period ${ }^{43}$ are referenced.

Interactivity is key here. A constellation of media is made accessible through the website itself. The user might review opinions aired on Twitter, where questions are raised regarding how we engage with material that is no longer there, starting with merely rhetorical questions: ("1916 Easter Rising Bolands Mills long gone, how do we remember and forget revolutions?” \#UCD1916 @ucdarchaeology); and moving towards more focused discussions of social conditions then and now ("\#UCD1916 the absence of any women's names in Yeats poem reflected the male dominant cultural discourse - something that is changing in 2016"). Other tweets might start discussions on the by-products of the commemoration, or about the re-materialization of what is no longer there.

Archives trickle into the everyday: "Commemorative stamps are out \#witnesshistory \#EasterRising @ireland2016 @Postvox- But do you like them? Right people?" Immaterial and non-visual information thus circulates. Similarly, on the Century Ireland website, the recollection process of the death of 16-year-old Mary Redmond starts with a song and goes on with the voices of interviewees at Glasnevin Cemetery, recalling how the girl was killed by a random bullet on her doorstep. Such assemblages of sound, story and place has the user re-imagine the relationships and the boundaries. The platform gives us an opportunity to think in terms of intensities, not just in terms of binaries, "us and them", "then and now" because it shows processes and encounters and emphasizes "thresholds and tensions, blends and blurs ${ }^{44}$ " rather than fixity. This is exemplified by the release of records by the Dublin Metropolitan Police or of testimonies presented in the RTE History Show: 1916 Eyewitness Accounts from the National Folklore Collection $^{45}$. Mimetic communication entails an emotional contagion, a circulation between bodies which leads into "more immediate, visceral, non-intentional ways in which bodies are conscripted by media technologies ${ }^{46 ", ~ L i s a ~ B l a c k-~}$ man writes.

Ubiquitous and shared authorship also denotes the point where "the extraordinary is now also the ordinary - the myth is also the everyday ${ }^{47}$ ". The digital platform indeed conveys positive knowledge by offering new contents from the DRI (Digital Repository of Ireland), but something happens that also creates new

43. [http://www.rte.ie/centuryireland/index.php/articles/lesson-plan-national-gallery-of-ireland] (last accessed January 11, 2017).

44. Gregg and Seigworth, The Affect Theory Reader, p. 4.

45. [http://www.rte.ie/centuryireland/index.php/listen/rte-the-history-show-dublin-metropolitan-police-files] and [http://www.rte.ie/centuryireland/index.php/listen/rte-history-show-1916-eyewitness-accounts-from-the-national-folklore-collec] (last accessed January 11, 2017).

46. L. Blackman, Immaterial Bodies..., op. cit., p. 18.

47. A. Vierkant, "The Image-Object Post-Internet...", op. cit. 
entanglements. And this, Vierkant argues, is one of the challenges of change the post-Internet era :

The goal of organizing appropriated cultural objects after the Internet cannot be simply to act as a didactic ethnographer but to present microcosms and create propositions for arrangements or representational strategies which have not yet been fully developed. Taking a didactic stance amounts to perpetuating a state of affairs of art positioned in contradiction to an older one-to-many hierarchy of mass media ${ }^{48}$.

By making incursions into ways of articulating new relationships and new objects (archived voices and testimonies, everyday stories and objects, the city or nation then and now) the platform enhances potentialities and unlocks the door to creativity. The website triggers intergenerational and aesthetic connections. For this not just a "mature" affair involving adults: the stories of children and older civilians are acknowledged through archives, whether as suppressed lives or voices, refuting the idea that the Rising was a rather small and absurd affair. Indeed on the community's level, it was not. Connections between the members of a family and relatives were reactivated during the commemorations. Most notably, this is the case of the series of YouTube videos produced by RTÉ for Century Ireland, which involved relatives of individuals who took part in the Rising, either on the rebels' side or as police ${ }^{49}$. Another effect of the website was to bridge the gap between the younger "digital natives" who "see digital technologies as the primary mediators of human-to-human connections" and their parents who are often seen as "digital immigrants s". $^{50}$

The impact and the effect of forgotten voices from the past is substantial and it means that Century Ireland avoids being utterly haptic. It succeeds in addressing "the way in which affects, trauma, forms of shames and so forth are communicated intergenerationally ${ }^{51}$ ". Sociologist Vikki Bell has stressed elsewhere the importance of "'generational carnal connection"5", while Paul Connerton has emphasized the importance of "relationships which are transmitted by mediums and practices other than the speaking subject: this might include film,

\section{Ibid.}

49. The programme "1916 Primetime Special: Was the Rising Justified?" was presented by David McCullagh and Miriam O’Callaghan from the GPO. Broadcast 23 March 2016. "Part 1 features a report by Barry Cummins in which he explores the background to the Rising with contributions from historians and the families of Volunteers, policemen and British soldiers including Dr Fearghal McGarry, Prof. Charles Townsend, Prof. Diarmaid Ferriter, Ruth Dudley Edwards." [https://www.youtube.com/watch?v=BtW1YXfsCZI] (last accessed June 26, 2017).

50. J. Pybus, Networked Affect..., op. cit., p. 215.

51. L. Blackman, Immaterial Bodies..., op. cit., p. xx.

52. Cited by L. Blackman, p. xx (quoting V. Bell, Culture and Performance, The Challenge of Ethics, Politics and Feminist Theory, Oxford, Berg, 2007). 
television, photographs, fiction and less inscribed, more embodied practices of remembering 53 ".

Another modality of the circulation of the archive is the creative form taken by The Sackville Street Art Project, which proposes to symbolically commemorate some of the 262 dead civilian dead through the creation of 3-D houses evocative of their lives ${ }^{54}$. The community-based artistic project aimed to create actual, not virtual objects in the form of personalized "houses" symbolizing lost innocent lives. The guidelines for potential artists might come across as slightly disturbing however, because they require that an individual or a group "pick a dead civilian" - much in the way that classrooms were made to support a (live) soldier in the 1914, or "marraines de guerre" (war godmothers) wrote to men in the trenches to boost their morale in France. The archival dimension is still at the heart of the project and attests to its legitimacy, but it also allows to expand into an individual reading of the events.

Another instance of this would be The Little Museum's "Little Stories, Little Prints" project, part of the 1916 Commemorative Visual Arts Project through Printmaking, which first went on display at the Ireland Funds Gallery, January $16-25,2016^{55}$. The prints speak of experiences of political and intimate time; of hauntings and ineffable loss, combining the use of online archive with the medium of the (very) "pre-internet" prints, which are also rendered accessible online.

\section{橉 Conclusion}

Century Ireland thus offers a rich virtual terrain though which issues of transmission and reception are addressed. It allows to assess new ways of dealing with the archives as users, and to consider how we interact and create with them in the age of the post-Internet, where the virtual mode has overwhelmingly become the default approach. While the archival material displayed by the website gives a new lease of life to the Rising as it multiplies the modalities of its visibility. It also opens up onto networks that enable users to relate to the events that are 100 years old, and to relate with others. As media theorists Gane and Beer claim, "The Internet is not simply a playground for self-publicizing individuals, for potentially it is also a site for new virtual communities and perhaps even the emergence of an

\section{L. Blackman, p. xx. (citing P. Connerton, How Societies Remember. Cambridge, CUP, 1989).}

54. See [http://1916sackvillestreet.com/] (last accessed Jan 11, 2017): "Welcome to the 1916 Sackville Street Art Project. Ireland is on the eve of a significant anniversary that is the centenary of the proclamation of the Irish Republic. There were more civilians killed during the 1916 Easter Rising than British Soldiers or Irish Volunteers. These men, women, and children who were killed have no memorial. They lie in graves in Dublin... some forgotten, until now..."

55. See [http://www.littlestorieslittleprints.com/] (last accessed January 11, 2017). 
'electronic agora' $[\ldots]^{56 "}$. All this takes archival material into different directions and connects it to new, often personal stories. Upon closer examination, Century Ireland appears to illustrate crucial changes in the public's approach to digital media and in their awareness of seamless connections between archive, networks, life and affect.

The platform avoids the obstacle of sticking with politically correct compassion and shifts towards a more ethically elevated perception of the Rising. This new perspective is in keeping with Lauren Berlant's statement that "To be moved by the suffering of some others (the 'deserving' poor, the innocent child, the injured hero), is also to be elevated into a place that remains untouched by other others (whose suffering cannot be converted into my sympathy or admiration) $)^{57}$." Countering the assumption that the new media age is one of "me-centered" individuals, Century Ireland, with its wealth of entries and material, fuels compassion, sympathy and aesthetic creation. It evidences the vitality of a combined reflexivity on Irish history, its commemoration, as well as its creative restitution.

56. N. Gane, D. Beer, New Media..., op. cit., p. 78.

57. Quoted by S. Ahmed, The Cultural Politics of Emotion, op. cit., p. 192. 